Anatoly Povoroznyuk, Oksana Povoroznyuk, Khaled Shekhna

National Technical University "Kharkiv Polytechnic Institute", Kharkiv, Ukraine

\title{
APPLICATION OF FRACTAL PROCESSING OF DIGITAL MAMMOGRAMS IN DESIGNING DECISION SUPPORT SYSTEMS IN MEDICINE
}

\begin{abstract}
The subject of the research is the methods of digital processing of halftone medical images with locally concentrated features. The object of the research is the process of morphological analysis of digital mammograms in the design of decision support systems in medicine. The aim of this work is to develop methods and technologies for detecting of diagnostically significant characteristics of digital mammograms based on their morphological analysis, taking into account fractal dimensions. The objective of the study is to improve the quality of mammographic examinations of patients in the design of decision support systems in medicine by developing specialized methods for morphological analysis of digital mammograms (highlighting diagnostically significant elements amid noises), based on taking into account the features of the images in the form of useful signal models, in particular, fractal dimension models. Research methods: a method for calculating the fractal dimension of two-dimensional halftone images specified on a discrete set, methods of object-oriented programming, methods of statistical analysis. As a result of the research, the following results were obtained: based on the analysis of known methods of digital image processing, a limited area of their application in processing mammograms was shown and the urgency of developing specialized methods of morphological analysis based on taking into account the features of the considered images in the form of useful signal models, in particular, fractal dimension models. A method and an algorithm for the implementation of morphological analysis of digital mammograms, taking into account their fractal dimension, have been developed. The software implementation of the method was performed using the MatLab math package and testing on real mammograms was completed. Mammograms without obvious pathologies and mammograms which having pathological structures of various types (tumors, intraductal formations and microcalcifications) were processed. The fractal dimension of the entire image and selected fragments was calculated. Conclusions. The results of the research showed that the fractal dimension of the entire image does not give statistically significant results on the presence or absence of pathologies, but if we calculate the fractal dimension on the selected fragments, then the results are very different. We can trace the pattern that the more obvious pathologies on a fragment, the greater the fractal dimension. Further research is aimed at developing a method for classifying digital mammograms taking into account their fractal dimensions.
\end{abstract}

Keywords : decision support system; medical image, morphological analysis, mammogram, fractal dimension.

\section{Introduction}

The introduction of computer and information technologies in medical practice has led to the creation of a wide range of medical information systems (MIS) from electronic medical records to complex decision support systems (DSS) $[1,2]$. The most widespread MIS are included in diagnostic complexes, with the help of which various instrumental examinations of patients are carried out.

The overwhelming majority of diagnostic information contains data obtained during visualization and morphological analysis (isolation of diagnostically significant structural elements amid noises) of biomedical signals and images [2]. Medical images (Xrays, mammograms, ultrasound, etc.) are one of the important means of obtaining visual information about the internal structure and function of the human body, which is not directly perceived by sight.

The information processing process in biomedical DSSs consists of a sequence of corresponding stages, one of which is the stage of morphological analysis of biomedical images (BMI) with locally lumped signs (LLS) [3, 4]. BMI with LLS are images with a structure in which diagnostic signs are focused on small fragments of their definition area. The task of morphological analysis is to isolate informative fragments (structural elements) of BMI amid noises, as a result of which diagnostic signs are formed in the form of parameters of the found structural elements [5].
Morphological analysis of BMI with LLS is one of the crucial stages, since errors at this stage lead to the making of erroneous diagnostic decisions or to a refusal from making a decision at all. This stage requires the use of specialized methods of morphological data analysis, taking into account the features of BMI with LLS and methods of their transformation $[6,7]$. The theory of morphological analysis has been most fully developed for processing images and scenes of various types $[8,9]$. However, in medical practice, for morphological analysis of BMI with LLS, various heuristic processing methods, which intuitively operate with the concept of the shape of structural elements in the image or in certain areas of the image, are often used.

The existing methods of digital processing do not take into account the peculiarities of BMI with LLS, have a limited scope of application for processing medical images, since these images are low-contrast, contain a significant noise component, and diagnostic elements have significant variability. In addition, some elements have an irregular (fractal) structure (for example, microcalcifications in mammography).

Therefore, an urgent task is to develop specialized methods for improving visualization and morphological analysis, based on taking into account the features of the considered images in the form of useful signal models, in particular, fractal dimension models, in order to improve the quality of instrumental examination of a patient during designing decision support systems in medicine based on morphological analysis of BMI with LLS. 
The aim of the work is to develop methods and information technologies for detecting diagnostically significant characteristics of halftone medical images based on their morphological analysis, taking into account fractal dimensions.

\section{Development of a method for morphological analysis of digital mammograms taking into account their fractal dimension}

Digital image processing has long been an integral part of research in almost all fields of science. Working with samples from any subject area involves not only extracting some data from images, but also classifying images, working with complex-structured samples, with non-obvious patterns and features that are often noticeable only to specialists in this field.

In medicine, the ability to automatically process large sets of images, to recognize images of internal organs in certain subject areas of medicine, to determine the type of tissue, to detect tumors, to determine the presence of any compounds can significantly affect the course of research, facilitate the process of working with images, for example, speed up the detection of a disease, making a diagnosis, which helps to choose timely and adequate treatment.

One of the widely used approaches to image analysis is fractal analysis [10]. Fractals, according to B. Mandelbrot's definition, are sets for which their fractal dimension is greater than topological. As a rule, such sets possess self-similarity properties. The characteristic that reflects this self-similarity is fractal dimension.

The approaches that are non-traditional for classical geometry, which are used in fractal analysis, help to obtain new data about the object under study, to analyze its rather complex, irregular structure.

During calculating the fractal dimension of various natural and artificial objects, a number of problems arise due to the fact that there are several definitions of fractal dimension. The basic concept is the Hausdorff dimension, but its estimation is often quite difficult. Therefore, in practice, dimensions related to the so-called boxcomputing (or box-counting) class [10] are often used.

With this approach, the set under study is covered by unit cells (boxes) of the same size $\delta$ and the number of elements of the covering $N(\delta)$ is considered. It is assumed that this number depends to some extent on the cell size $\delta$. It is considered the relation

$$
f=\log _{2} N(\delta) / \log _{2}(\delta)
$$

and its behavior with a change in the scale $\delta$ is investigated. If there is a limit of this ratio, then it is equal to the number $d$, which is called the fractal dimension of this set

$$
d=\lim _{\delta \rightarrow 0} f=\lim _{\delta \rightarrow 0}\left(\log _{2} N(\delta) / \log _{2}(\delta)\right) .
$$

For a point, segment, square, etc., this value coincides with the well-known geometric dimension and is an integer ( $d=0,1,2$, respectively). For fractal sets, the dimension is not an integer. Thus, the main idea of introducing this class of dimensions is the concept of "measurement on the $\delta$ scale": for each $\delta$, an object is measured in such a way that the unevenness of objects smaller than $\delta$ is ignored and measurements are considered when $\delta$ tends to 0 .

Direct determination of the fractal dimension according to (1) is used in the analysis of binary images, but to determine the fractal dimension of halftone images one of the methods described in $[11,12]$ is used. The idea of the method is to build the surface of the graph of the grayscale function, calculate the volume of a special "cover" for this surface, and then calculate the fractal dimension of the surface.

It turns out that in this case the Minkowski's dimension coincides with the most commonly used capacitive one, but the calculation method is simpler. Thus, a dimension vector is compared to each image, and the proximity of the images is estimated by the proximity of the vectors.

The method is based on plotting the surface of the grayscale function over a grayscale image. Then this surface "thickens" - a special $\delta$-parallel body, the socalled cover, is built for it. Its volume, approximation to the surface area and the fractal dimension of the surface are calculated.

Let a set of points be given for a halftone image

$$
F=\left\{Z_{i j}, i=\overline{0, k}, j=\overline{0, l}\right\}
$$

where $Z_{i j} \in\{0,255\}$ is the intensity value for a pixel with coordinates $(i, j)$.

Since grayscale is only defined for a pixel, $F$ can be considered as a function of integer arguments. Let us extend $F$ for points with real coordinates (x, y), $i \leq x<i+1, j \leq y<j+1$, then we can talk about the surface area of the graph of the constructed function $F$ (we can add it with the values of $Z_{i j}$ or using any approximation).

If we consider the resulting surface as a fractal, then the fractal dimension is determined by the value of its area. In image analysis, the set of grayscale function values is always not empty and is limited in $R^{3}$.

Let's consider all points located at a distance $\delta$ from the surface of the graph of the grayscale function. They form a "cover" with a thickness of $2 \delta$, which is a $\delta$-parallel body and is defined by the upper surface $u_{\delta}(i, j)$ and the lower surface $b_{\delta}(i, j)$. For $\delta=1,2, \ldots$ the surfaces are determined iteratively:

$$
\begin{gathered}
u_{\delta}(i, j)=\max \left\{u_{\delta}(i, j)+1, \underset{|(m, n)-(i, j) \leq 1|}{\max } u_{\delta}(m, n)\right\} \\
b_{\delta}(i, j)=\min \left\{u_{\delta}(i, j)-1, \quad \min _{|(m, n)-(i, j) \leq 1|} u_{\delta}(m, n)\right\}
\end{gathered}
$$

It can be seen from $(2,3)$, that in the calculations of the extreme points we use four nearest neighbors.

A point $F(x, y)$ is included in a $\delta$-parallel body if

$$
b_{\delta}(i, j) \leq F(x, y)<u_{\delta}(i, j) .
$$

The volume of a $\delta$-parallel body is calculated as

$$
V_{\delta}=\sum_{i, j}\left(u_{\delta}(i, j)-b_{\delta}(i, j)\right)
$$

The surface area of the fractal is calculated by the following formula 


$$
S_{\delta}=V_{\delta} /(2 \delta)
$$

Since $S_{\delta} \approx \beta \delta^{2-D}$ [4], the fractal dimension $D$ is determined from the relation:

$$
D=2-\log _{2} S_{\delta} / \log _{2} \delta .
$$

Calculation of the surface area of the graph of the function $F$ can be performed for the entire image or we can divide it into cells with coordinates $(\mathrm{x}, \mathrm{y})$ and perform calculations for each cell.

Considering that the fractal dimension $D$ calculated according to (6) will differ for different $\delta$, the average value of the ratio

$$
\log _{2} S_{\delta} / \log _{2} \delta
$$

is found by the method of least squares as the slope coefficient $a_{1}$ of the straight line $y=a_{0}+a_{1} x$ in coordinates $x=\log _{2} \delta ; y=\log _{2} S_{\delta}$.

Based on the above, the following algorithm for calculating the fractal dimension of halftone images is proposed

1. For the whole image or for a selected fragment, construct a grayscale function $Z_{i j}$.

2. Determine the initial values of the twodimensional array of points of the upper and lower surfaces of the $\delta$-parallel body for $\delta=0$ :

$$
u_{0}(i, j)=b_{0}(i, j)=Z(i, j), i=\overline{0, k}, j=\overline{0, l}
$$

3. Organize a cycle of changing the scale $\delta$ $(\delta=\overline{1,256})$, at each stage of which the following actions are performed:

3.1. Two-dimensional arrays of points of the upper $u_{\delta}(i, j)$ and lower $b_{\delta}(i, j)$ surfaces of a $\delta$-parallel body are calculated by formulas (2) and (3).

3.2. The volume of a $\delta$-parallel body $V_{\delta}$ is calculated by the formula (4).

3.3. The surface area $S_{\delta}$ of the fractal is calculated by the formula (5).

3.4. The values $\log _{2} \delta$ and $\log _{2} S_{\delta}$ are calculated and stored in the corresponding arrays.

4. By the method of least squares calculate the coefficient $a_{1}$ of the linear regression of the form $y=a_{0}+a_{1} x$ in coordinates $x=\log _{2} \delta ; y=\log _{2} S_{\delta}$. The calculated value is taken as the average value of the ratio (7), which is then used in the formula (6).
5. Using formula (6), find the fractal dimension of an image or a selected fragment.

\section{Software implementation and testing}

During developing a software implementation of the above algorithm for calculating the fractal dimension, is was substantiated the choice of the Windows operating system (OS), which occupies almost $90 \%$ of the OS market for personal computers.

The calculations were performed using the mathematical package MATLAB [13], which provides convenient tools for developing algorithms, including high-level ones, using the concepts of object-oriented programming. It contains all the necessary IDE tools, including a debugger and profiler. In addition, MATLAB has the ability to access its built-in functions through the $\mathrm{C}$ interface, which allows the package functions to be used in external $\mathrm{C}$ applications.

The developed software product "FractalMed" is written in $\mathrm{CH}$ and uses a computational module for calculating the fractal dimension, which is developed in the MATLAB environment and is connected to the main program in the form of a DLL module. The software product has the following capabilities: opening an image of various formats; opening files of images of mammograms with the extension .mam; image view; approach and distance; selection of the area for calculating fractal dimension; calculation of the fractal dimension of the image.

The developed software product was tested on real mammogram images. Mammogram files in $*$.mam format were kindly presented by the developers of domestic mammographs - the company "Radmir", Kharkov. 60 mammograms were analyzed, among them 40 were without obvious pathologies and 20 had pathological structures of various types (tumors, intraductal formations and microcalcifications).

The fractal dimensions of the analyzed mammograms and their selected fragments were calculated. In this case, the first fragment was selected a fragment without obvious pathologies, the second was with obvious pathologies. Examples of processed medical images are shown in Fig. 1. The processing results are shown in table 1.

Table 1 shows the processing data of mammogram files: 0157.mam - without obvious pathologies; 0111.mam - pathological formation (dark spot on the mammogram) 0120.mam - microcalcifications; 0162.mam - intraductal formations.

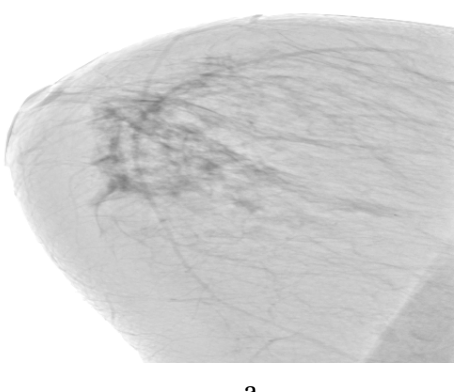

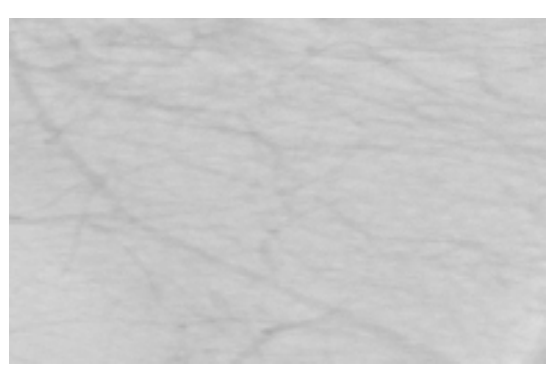

b

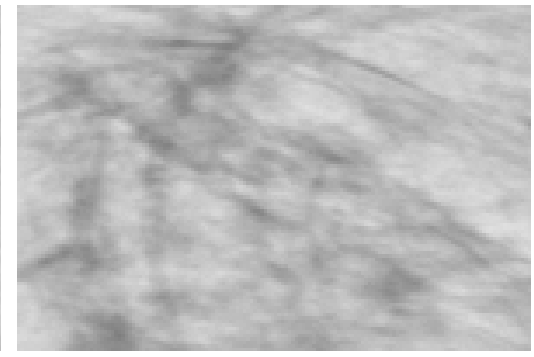

$\mathrm{c}$

Fig. 1. Examples of processed images a - file 0120.mam, b - fragment without pathologies of file 0120.mam, $c$ - fragment with pathologies of file 0120.mam 
Table 1 - Results of testing of the real medical images

\begin{tabular}{|c|c|c|c|}
\hline \multirow{2}{*}{ File name } & \multicolumn{3}{|c|}{ Fractal dimension of^ } \\
\cline { 2 - 4 } & $\begin{array}{c}\text { the } \\
\text { whole } \\
\text { image }\end{array}$ & $\begin{array}{c}\text { a fragment without } \\
\text { obvious pathologies }\end{array}$ & $\begin{array}{c}\text { a fragment } \\
\text { with obvious } \\
\text { pathologies }\end{array}$ \\
\hline $157 . \mathrm{mam}$ & 2,466 & 2,495 & 2,711 \\
\hline $0111 . \mathrm{mam}$ & 2,414 & 2,531 & 2,683 \\
\hline $0120 . \mathrm{mam}$ & 2,402 & 2,482 & 2,702 \\
\hline $0162 . \mathrm{mam}$ & 2,482 & 2,681 & 2,650 \\
\hline
\end{tabular}

Analyzing the data of table 1 , we can conclude that the fractal dimension of the whole image does not give statistically significant results on the presence or absence of pathologies; in all images, the fractal dimension lies in the range from 2.4 to 2.5. But if we make calculations of the fractal dimension on the selected fragments, then the results are very different. It is possible to trace the pattern that the more obvious pathologies on a fragment, the greater the fractal dimension.

\section{Conclusions}

The application of fractal processing of halftone medical images to identify diagnostically significant characteristics has been substantiated. A method has been developed for identifying diagnostically significant characteristics of halftone medical images based on their morphological analysis, taking into account fractal dimensions.

An algorithm for calculating the fractal dimension of medical images or selected fragments and its software implementation have been developed. The program has been tested on real mammograms.

Further research is aimed at developing a method for the classification of halftone medical images taking into account their fractal dimensions.

\section{REFERENCES}

1. Avrunin, O.Gh. and Bodjansjkyj, Je.V. (2018), Modern intellectual technologies of functional medical diagnostics: monograph, KhNURE, Kharkiv, 236 p. (in Ukrainian).

2. Povoroznyuk, A. I. (2011), Decision support systems in medical diagnostics. Synthesis of structured models and decision rules, LAP LAMBERT Academic Publishing GmbH \& Co. KG, Saarbrücken Germany, 314 p. (in Russian).

3. Povoroznyuk, A.I., Povoroznyuk, O.A. and Mumladze, G. R. (2019), "Development of a functional model of the stages of diagnostic and therapeutic measures in decision support systems in medicine", Control, navigation and communication systems, Issue 2 (54), PNTU, Poltava, pp.144-148 (in Russian).

4. Povoroznyuk, A.I. and Filatova, A.E. (2019), "Formalization of the problem of the matched morphological filtering of biomedical signals and images", Information Technology in Medical Diagnostics II: Proc. of the International Scientific, Internet Conf. «Computer Graphics and Image Processing» and the XLVIIIth International Scientific and Practical Conf. «Application of Lasers in Medicine and Biology», CRC Press, London, UK, pp. 155-162.

5. Guo, Q., Ruiz, V., Shao, J. and Guo, F. (2005), "A novel approach to mass abnormality detection in mammographic images", Proceedings of the IASTED International Conference on Biomedical Engineering, Innsbruck, pp. 180-185.

6. Povoroznyuk, A.I., Filatova, A.E. and Kozak, L.M. (2017), "Grayscale morphological filter based on local statistics", The International Society for Optical Engineering, Vol. 10445, pp. 205-214.

7. Povoroznyuk, A.I., Filatova, A.E. and Shehna, Kh. (2019), "Development of Method of Matched Morphological Filtering of Biomedical Signals and Images", Automatic Control and Computer Sciences, Vol. 53, No. 3, pp. 253-262.

8. Rubis, A.Yu., Lebedev, M.A., Vizil'ter, Yu.V. and Vyglov, O.V. (2016), "Morphological filtering of images based on crosscontrast", Computer optics, Vol. 40, No. 1, pp. 73-79 (in Russian).

9. Yu.V. Vizilter, V.S. Gorbatsevich, A.YU. Rubis, O.V. Vygolov (2015) "Comparison of images by shape using diffuse morphology and diffuse correlation", Computer optics, Vol. 39, No. 2, pp. 265-274 (in Russian).

10. Ajay Kumar, Bisoi and Jibitesh, Mishra (2001), "On calculation of fractal dimension of images", Pattern Recognition Letters, Vol. 22, Issues 6-7, pp. 631-637.

11. Ampilova, N.B., Soloviev, I.P. and Shupletsov, Yu.V. (2014), "On Fractal, Statistical and Morphological Methods of Digital Image Analysis in Medical Research", Computer Science. Telecommunications and Control Systems, St. Petersburg State Polytechnical University Journal, No. 1 (188), pp. 51-61.

12. Povoroznyuk, A.I. and Shekhna, K.H. (2018), "Fractal processing of digital medical images in the design of decision support systems in medicine", Information technology and computer modeling; materials of articles of the International scientificpractical conference, Ivano-Frankivsk, May 14-19, Ivano-Frankivsk, Mr. Goliney OM, pp. 77-80 (in Ukrainian).

13. Dyakonov, V.P. (2012), MATLAB. Complete tutorial, DMK-Press, Moscow, 768 p. (in Russian).

Received (Надійшла) 14.09.2020

Accepted for publication (Прийнята до друку) 21.10.2020

\section{ВідОмості ПРо АвтоРів/ АвоUT тHE AUTHORS}

Поворознюк Анатолій Іванович - доктор технічних наук, професор, професор кафедри обчислювальної техніки та програмування, Національний технічний університет «Харківський політехнічний інститут», Харків, Україна; Anatoly Povoroznyuk - Doctor of Technical Sciences, Professor, Professor of Computer Engineering and Programming Department, National Technical University "Kharkiv Polytechnic Institute", Kharkiv, Ukraine; e-mail: ai.povoroznjuk@gmail.com; ORCID ID: https://orcid.org/0000-0003-2499-2350.

Поворознюк Оксана Анатоліївна- кандидат технічних наук, доцент кафедри обчислювальної техніки та програмування, Національний технічний університет «Харківський політехнічний інститут», Харків, Україна;

Oksana Povoroznyuk - Candidate of Technical Sciences, Associate Professor of Computer Engineering and Programming Department, National Technical University "Kharkiv Polytechnic Institute", Kharkiv, Ukraine; e-mail: povoks@i.ua; ORCID ID: https://orcid.org/0000-0001-7524-5641. 
Халед Шехна - аспірант кафедри обчислювальної техніки та програмування, Національний технічний університет «Харківський політехнічний інститут», Харків, Україна;

Khaled Shehna - post-graduate student of Computer Engineering and Programming Department, National Technical University "Kharkiv Polytechnic Institute", Kharkiv, Ukraine;

e-mail: khaled-shehna@hotmail.com; ORCID ID: https://orcid.org/0000-0003-1698-7797

Застосування фрактальної обробки цифрових мамограм при проектуванні систем підтримки прийняття рішень в медицині

\section{А. І. Поворознюк, О. А. Поворознюк, Х. Шехна}

Анотація. Предметом дослідження є методи цифрової обробки напівтонових медичних зображень 3 локально зосередженими ознаками. Об'єктом дослідження є процес морфологічного аналізу цифрових мамограм при проектуванні систем підтримки прийняття рішень в медицині. Метою роботи є розробка методів і технологій виявлення діагностично значущих характеристик цифрових мамограм на основі їх морфологічного аналізу 3 урахуванням фрактальних розмірностей. Завдання дослідження - підвищення якості мамографічних обстежень пацієнток при проектуванні систем підтримки прийняття рішень в медицині шляхом розробки спеціалізованих методів морфологічного аналізу цифрових мамограм (виділення діагностично значущих елементів на тлі перешкод), заснованих на врахуванні особливостей розглянутих зображень у вигляді моделей корисних сигналів, зокрема моделей фрактальної розмірності. Методи досліджень: метод розрахунку фрактальної розмірності двовимірних напівтонових зображень, заданих на дискретній множині, методи об'єктно-орієнтованого програмування, методи статистичного аналізу. В результаті проведення досліджень одержано наступні результати : на основі аналізу відомих методів цифрової обробки зображень показана обмежена сфера їх застосування при обробці мамограм і обгрунтована актуальність розробки спеціалізованих методів морфологічного аналізу, засновані на врахуванні особливостей розглянутих зображень у вигляді моделей корисних сигналів, зокрема моделей фрактальної розмірності. Розроблено метод і алгоритм реалізації морфологічного аналізу цифрових мамограм 3 урахуванням їх фрактальної розмірності. Виконана програмна реалізація методу за допомогою математичного макета MatLab i тестування на реальних маммограммах. Виконана обробка мамограм без явних патологій і таких, які мають патологічні структури різних типів (пухлини, внутрішньопротокові утворення $\mathrm{i}$ мікрокальцинати). Була розрахована фрактальная розмірність всього зображення i виділених фрагментів. Висновки. Результати дослідження показали, що фрактальна розмірність всього зображення не дає статистично значущих результатів про наявність чи відсутність патологій, але якщо робити розрахунки фрактальної розмірності на виділених фрагментах, то результати сильно відрізняються. Можна простежити закономірність, що чим більше явних патологій на фрагменті, тим більше фрактальная розмірність. Подальші дослідження спрямовані на розробку методу класифікації цифрових мамограм з урахуванням їх фрактальних розмірностей.

Кл юч ов і сл ов а : система підтримки прийняття рішень; медичне зображення; морфологічний аналіз; мамограма; фрактальна розмірність.

\section{Применение фрактальной обработки цифровых маммограмм при проектировании систем поддержки принятия решений в медицине} А. И. Поворознюк, О. А. Поворознюк, Х. Шехна

Аннотация. Предметом исследования являются методы цифровой обработки полутоновых медицинских изображений с локально сосредоточенными признаками. Объектом исследования является процесс морфологического анализа цифровых маммограмм при проектировании систем поддержки принятия решений в медицине. Целью работы является разработка методов и технологий обнаружения диагностически значимых характеристик цифровых маммограмм на основе их морфологического анализа с учетом фрактальных размерностей. Задача исследования - повышения качества маммографических обследований пациенток при проектировании систем поддержки принятия решений в медицине путем разработки специализированных методов морфологического анализа цифровых маммограмм (выделение диагностически значимых элементов на фоне помех), основанных на учете особенностей рассматриваемых изображений в виде моделей полезных сигналов, в частности моделей фрактальной размерности. Методы исследований: метод расчета фрактальной размерности двумерных полутоновых изображений, заданных на дискретном множестве, методы объектно-ориентированного программирования, методы статистического анализа. В результате проведения исследований получены следующие результаты: на основе анализа известных методов цифровой обработки изображений показана ограниченная сфера их применения при обработке маммограмм и обоснована актуальность разработки специализированных методов морфологического анализа, основанные на учете особенностей рассматриваемых изображений в виде моделей полезных сигналов, в частности моделей фрактальной размерности. Разработан метод и алгоритм реализации морфологического анализа цифровых маммограмм с учетом их фрактальной размерности. Выполнена программная реализация метода с помощью математического макета MatLab и тестирование на реальных маммограммах. Выполнена обработка маммограмм без явных патологий и имеющие патологические структуры различных типов (опухоли, внутрипротоковые образования и микрокальцинаты). Была рассчитана фрактальная размерность всего изображения и выделенных фрагментов. Выводы. Результаты исследования показали, что фрактальная размерность всего изображения не дает статистически значимых результатов о наличии или отсутствии патологий, но если делать расчеты фрактальной размерности на выделенных фрагментах, то результаты сильно отличаются. Можно проследить закономерность, что чем больше явных патологий на фрагменте, тем больше фрактальная размерность. Дальнейшие исследования направлены на разработку метода классификации цифрових маммограмм с учетом их фрактальных размерностей.

Ключевые слова: система поддержки принятия решений; медицинское изображение; морфологический анализ; маммограмма; фрактальная размерность. 